\title{
Ultrasonographic, Hormonal, Morphological And Morphometric Correlate Studies of Induced Testicular Pathology In West African Dwarf Goat Bucks.
}

\author{
Raji L.O. ${ }^{1 *}$, Jubril A. J. ${ }^{2}$, Raheem A. K. ${ }^{3}$, Jaji A. Z. ${ }^{4}$, Adam M. ${ }^{5}$, \\ Olatunji A. O. ${ }^{6}$ and Suleiman K. Y. ${ }^{7}$. \\ ${ }^{1}$ Department of Theriogenology and Production, University of Ilorin, Ilorin, Nigeria. \\ ${ }^{2}$ Department of Veterinary Pathology, University of Ibadan, Ibadan, Nigeria. \\ ${ }^{3}$ Department of Theriogenology, Michael Okpara University of Agriculture, Umudike, Abia State, Nigeria. \\ 'Department of Veterinary Anatomy, University of Ilorin, Ilorin, Nigeria. \\ ${ }^{5}$ Department of Veterinary Pathology, University of Ilorin, Ilorin, Nigeria. \\ 'Department of Veterinary Pharmacology and Toxicology, University of Ilorin, Ilorin, Nigeria. \\ ${ }^{7}$ Department of Veterinary Physiology and Biochemistry, University of Ilorin, Ilorin, Nigeria.
}

Accepted January, 2019 and Published February, 2019

\begin{abstract}
The study was carried out to evaluate the significance of ultrasound in the early detection of testicular pathology in the West African Dwarf (WAD) buck; hormonal, morphological and morphometric studies were used as correlates. Twelve matured WAD bucks divided into two groups (of6 per group); $A$-control, B-bucks with right testis spermatic cord ligated for four weeks were used for this study. Testicular ultrasound protocols were carried on the Longitudinal Planes (LP) and Transverse Planes (TP) on both testes. Blood samples were collected via the jugular vein twice a week for four weeks and assayed for testosterone, Luteinizing Hormone (LH) and Follicle Stimulation Hormone (FSH) concentrations. The testes were harvested after four weeks and carefully separated from the epididymides for gross and histological studies. Results revealed that 24 hours post induction of testicular pathology, inflammation of the right testes of the group $B$ bucks was detected by ultrasound as hypo-echoic (dark) regions covering about two-third of the entire testis while the non-ligated testes appeared mostly homogeneously greyish on the TP. By the end of the fourth week the entire ligated testes were inflamed and appeared hypo-echoic with some areas of fibrosis on the TP and LP. The LH and FSH concentrations increased while there were no significant changes in testosterone concentrations. There were marked reduction in testicular and epididymal weights and sizes in group B bucks. The group B bucks testes showed complete loss of

"Corresponding Author:

Email: raji.lo@unilorin.edu.ng,

Tel:+2348038261951
\end{abstract}


testicular architecture while the Leydig cells were intact. In conclusion, testicular ultrasound was valuable in the early detection of the induced testicular pathology (which hormonal, morphological and morphometric studies confirmed), hence should be adopted as part of the BSE programme of the WAD buck.

Keywords: Breeding soundness examination, Testicular pathology, Ultrasound, West African Dwarfbucks

\section{INTRODUCTION}

Reproductive disease conditions such as orchitis, epididymitis, testicular torsion and ischaemia are occasionally encountered during Breeding Soundness Examination (BSE) in the goat bucks [ 1, 2]. Early detection and understanding of the pathogenic effects of these disease conditions which can affect fertility is of paramount importance for prompt diagnosis, management and improved production [3, 4]. However during BSE, the routine palpation method may not be enough to detect an emerging or (in some cases) hidden testicular and epididymal disease conditions. Hence, the use of procedures such as Testicular Ultrasound (TU) has been found to be valuable in these situations $[5,6,7,8]$. The TU is a non-invasive technique that has been used and reported for diagnosis of disease conditions of the testes and epididymides in some domestic animals and humans but its use in WAD goat buck is yet to be fully established. The TU can detect testicular and epididymal damages early enough to effect treatment $[9,10,11]$. Also, often, some of these disease conditions have major deleterious effects on reproductive hormones, such as testosterone, FSH and LH which play significant roles in goat buck reproduction [12, 13, 14]. Testosterone plays key roles in the development of the testes, prostate and production of spermatozoa. Apart from these, it also increases libido and frequency of erection as well as secondary sexual characteristics amongst other numerous roles in the goat bucks $[15,16]$. The $\mathrm{LH}$ also known as Interstitial Cell Stimulating Hormone (ICSH) is produced by gonadotroph cells in the anterior pituitary and is responsible for the stimulation of the production of testosterone by the Leydig cell acting synergistically with the FSH. Its production is under the influence of Gonadotropin Releasing Hormone ( $\mathrm{GnRH})$ which is produced from the hypothalamus $[17,18]$. The FSH which is also synthesized and secreted by the anterior pituitary, stimulates the proliferation and secretory activities of the sertoli cells. Sertoli cells function majorly to aid spermatogenesis, move developing sperm cells to the lumen of the seminiferous tubules and to reduce motility and capacitation of sperm cells to maintain viability $[19,20]$. However, studies on these reproductive hormones which may be required in the diagnosis of disease conditions and resultant pathogenesis in the WAD bucks are very scarce. In severe cases and/or death, gross and histopathologic studies may be required to diagnose these disease conditions [21, 22]. However, gross and histopathology studies of the testes and epididymides as correlates of ultrasonographic changes observed for pathologic lesions in this species are scarce. These studies are meant to provide details of the pattern of the disease conditions and how they affect the testicular architecture and functions. Therefore, this study was conducted 
to evaluate the significance of $\mathrm{TU}$ as a diagnostic tool in the early detection of pathology of the testes and epididymides in the WAD bucks, using hormonal, morphological and morphometric studies as correlates.

\section{MATERIALSAND METHODS \\ Animal management and grouping}

Twelve (12) eight months old WAD bucks with the average body weight of $9.1 \pm 0.37 \mathrm{~kg}$ and Scrotal Circumference of (SC) of $17.62 \pm 0.52$ $\mathrm{cm}$ were used for this study. Scrotal shape, anatomy, and content as well as testicular consistency and size were thoroughly examined to be normal. The goats were stabilized for four weeks. They were given procaine penicillin antibiotic treatment for five days and ivermectin as both endoparasitic and ectoparasitic agent. Thereafter, the animals were vaccinated against Peste des petits ruminants (PPR) viral infection. They were fed with hays supplemented with cassava and yam peels. They were allowed to roam around their pen within a confined area in order to have access to grass. They were also provided with water ad-libitum. Good hygiene practice was maintained throughout the course of the study. The bucks were grouped into two comprising of six bucks in each group; A - control and B right testis spermatic cord ligated.

\section{Induction of testicular pathology}

This was done by using a size 4 scalpel blade to make an incision from the dorso-medial aspect of the testis proximal to the external inguinal orifice. The skin was reflected laterally and the subcutaneous tissue and scrotal fascia were incised to expose the vagina tunic. The spermatic cord was then ligated using size 2-0 chromic catgut. The incision site was sutured using a size 2-0 nylon suture and sprayed with antibiotics. The ligations were left for four weeks before the testes were harvested and carefully separated from the epididymides using scalpel blade.

\section{Blood sample collection and handling}

Blood were collected from the bucks via the jugular vein into non-heparinized sample bottles twice a week for four weeks. The blood samples were allowed to clot then centrifuged at 3000 revolutions for 30 minutes to separate the serum. The serum samples were carefully decanted into plain bottles and stored in a deep freezer at $-40^{\circ} \mathrm{C}$ until used.

\section{Hormonal assay procedure}

The serum samples were assayed for serum concentrations of testosterone, FSH and LH using Enzyme-Linked Immunosorbent Assay (ELISA) according to the manufacturer's instructions.

\section{Testicular Ultrasound protocol}

Testicular ultrasound protocol was carried out on both testes of all the bucks in groups A and B by viewing on the TP and LP. The right and left testes were viewed on TP and LP respectively, thereafter, both testes were viewed on TP [23].

\section{Gross biometrics}

Weight of the right and left testis: This was taken by using a digital weighing balance OHAUS $^{\circledR}$ (by OHAUS co-operations).

Volume of the right and left testis: This was taken by using the Water Displacement Method (WDM) as described by [23]. Briefly, the testis is put in cylinder filled with normal saline; the volume of the testis is taken as the volume of normal saline it displaces in the cylinder (while avoiding error due to parallax). 
Total length of the right and left epididymides: This was taken by using a measuring ruler [24].

\section{Histological procedure}

Testicular and epididymal samples were taken from group A and B bucks, fixed in Boiun's fluid and histological procedures carried out as described earlier $[24,25,26]$.

\section{Statistical analysis}

Data were expressed as Mean $\pm \mathrm{SD}$ and analyzed using Student t-test at $\mathrm{P}<0.05$ (using SPSS version 20).

\section{Results}

\section{Ultrasound results}

The sonogram of the group A bucks were normal for both testes on the TP and LP. For the group B bucks, 24 hours post ligation of the spermatic cords, the testes were slightly inflamed and these appeared on the TP as hypoechoic (dark) regions covering about two-third of the entire testes but the scrotal walls were still intact while the non-ligated testes appeared mostly greyish with normal testicular architecture (Figure 1a). At the end of the second week there were slightly hypo-echoic areas at the anterior portion and entirely hypoechoic regions on the posterior aspect of the left testes of the non-ligated testes on the TP (Figure 1b). These hypo-echoic regions covered about two-third of the non-ligated testes at the end of the third week while the ligated testes were almost entirely of hypo-echoic areas (Figure 1c). At the end of the fourth week the entire ligated testes and majority of the non-ligated testes were inflamed and appeared as hypo- echoic regions with loss of testicular architecture and some areas of fibrosis (hyperechoic regions) on the LP for the ligated testes (Figure 1d).

\section{Hormonal assay results}

Results of hormonal analyses revealed that there were no significant differences in the testosterone concentrations of the group A (control) and group B (right testis ligated) bucks throughout the course of the experiment $(\mathrm{P}<0.05)$ (Figure 2). However, there were significant increases in the level of $\mathrm{LH}$ concentrations of group B bucks when compared with those of group A bucks at the end of week one ( $P=0.02)$, week two ( $P=$ $0.03)$, week three $(\mathrm{P}=0.02)$ and week four $(\mathrm{P}=$ $0.01)$ respectively. There were also significant increases in group B bucks' serum LH concentration from week one to week two $(\mathrm{P}=$ $0.01)$, week two to week three $(P=0.02)$ and week three to week four $(\mathrm{P}=0.02)$, in a chronological pattern respectively (Figure 3 ). There were significant increases in the concentrations of FSH in group B compared with group $\mathrm{A}$ bucks at the end of week one $(\mathrm{P}=$ $0.01)$, week two $(P=0.02)$, week three $(P=$ $0.01)$ and week four $(P=0.02)$ respectively. There were also significant increases in group B bucks' serum FSH concentrations from week one to week two $(P=0.02)$, week two to week three $(\mathrm{P}=0.01)$ and week three to week four $(\mathrm{P}$ $=0.03$ ), in a chronological pattern respectively (Figure 4). The serum FSH concentration had a similar pattern to that of $\mathrm{LH}$ throughout the course of the experiment.

\section{Gross lesions and biometrics results}

There was marked reduction in the sizes, weights and volumes of the ligated testes compared with the non-ligated testes in group 
B, also when compared with those of group A bucks. There was loss of testicular architecture and normal arterial network of the ligated testes. On incision, general degeneration of testicular tissue was observed. There was marked reduction in the sizes of the epididymides of group B bucks compared with those of group A. Gross biometrics results for the testes and epididymides for all the bucks for both groups were as presented in Tables 1 and 2 respectively.

\section{Histopathology results}

The histopathology of the ligated testes revealed complete loss of testicular architecture with the non-division of the Seminiferous Tubules (ST) into regular septae. There was also no evidence of germinal epithelial cell layers. There were very scanty sperm cells most of which were eviscerated out of the ST into the adjacent connective tissues (Figure 5a). The head, body and especially the tail of the epididymides were highly depleted of sperm cells and there was complete loss of epithelial layers (Figures 5b, c and d). The sections from the group A bucks (non- ligated testes) showed normal architecture.

\section{DISCUSSION}

In the current study ultrasound was useful in the early detection of the induced pathologic conditions of the testes in WAD goat bucks, making the procedure valuable in the BSE examination in agreement to earlier reports in WAD bucks [23], in cattle [27] and in sheep [7]. The inflammatory and degenerative changes (induced by ligation of the spermatic cords) observed in the testes of the WAD bucks were detected by ultrasound 24 hours post induction of pathology and throughout the course of the experiment. These findings were similar to those reported in sheep rams and goat bucks by [28]. However, contrarily, [29] and [30] did not observe any clinical ultrasonographic changes in the testicular parenchyma of vasectomized adult rams during a 12-month post operative period and in adult rams and bucks respectively. Although, the procedures (i.e the pathology induced in the current study and the vasectomy in these previous studies) were invasive, ultrasound, a non-invasive procedure, was useful as a diagnostic tool in these studies.

It was also observed that there were no significant changes in the testosterone concentrations; however, there were significant increases the in LH and FSH concentrations. [28] reported similar scenario in terms of production of these hormones when they induced testicular ischaemia in matured goat bucks. Also, [31] and [32] reported similar pattern of these hormones production (in the current study) and stated that this is associated with testicular damage, repairs and regeneration. However, [33] reported increase in $\mathrm{LH}$ and FSH in response to low level of testosterone concentrations in matured Nubian goats. This further shows the importance of conducting researches in comparing normal and pathological reproductive conditions in these livestock animals as it is done in the current study.

Gross biometric result revealed that the sizes, weights and volumes of the ligated testes were markedly reduced to about halves of those of the intact testes. Also, grossly, there was loss of testicular architecture and normal arterial network of the ligated testes. [28] reported similar testicular pathological findings in Pakistan male goats and rams. However, the 
testes of the non-ligated testes were intact and similar to those described by [24].

Histopathology of the ligated testes revealed that there was major loss of testicular architecture. There was also loss of germinal cell layers. This is probably because the germinal epithelial layer is made of mitotic cells. Mitotic cells undergo degeneration at a high rate when affected as [34] also reported in bovine testes. However, the Leydig cells mostly appeared intact and unaffected probably because they are non-mitotic cells. This is similar to the observations by [35] in an experimentally induced ischemic-reperfusion on the testis in albino rats. There were very scanty sperm cells in the seminiferous tubules most of which were eviscerated into the adjacent connective tissues; similar to the report by [28] in Pakistan goats and rams. The head, body and especially the tail were highly depleted of sperm cells and there was complete loss of epithelial layers. [36] reported similar observation in mice testes dosed with Abrus precatorious $L$., however, the epithelial layers of the head, body and tail regions were not affected.

This study showed that TU is highly valuable in the early detection of pathologic conditions of the WAD buck testes and this correlates with the hormonal, morphological and morphometric parameters. This observation allows for early detection, intervention and treatment of disease conditions particularly those that cannot be detected easily by the routine palpation commonly practiced in the BSE programmes. Also, the data from the hormonal, morphological and morphometric studies will be useful in the diagnosis or comparative studies of related testicular disease conditions in these WAD bucks. Therefore, it is recommended that TU should be adopted as part of the BSE programme of WAD goat bucks for improved production.

\section{Conflict of interest}

We Authors declare that there is no conflict of interests.

\section{REFERENCES}

1. Chukwuka, O. K. Okoli, I. C. Okendo, N. J. Opasa, M. N. Herbert, U., Ogbuewu, I. P.and Ekenvem, B. U.( 2010). Reproductive Potentials of West African Dwarf Sheep and Goat: A Review. Research Journal of Veterinary Science, 3: 86-100.

2. Bousmaha, F. and Khoudija B. F. (2012). Comparative and pathological study of the

3. Testis and Epididymis in Rams, Bucks and Bulls of Algeria. Asian Journal of Animal and Veterinary Advances, 7 (10): $950-959$.

4. Raczykowski, C. (2002). Fertility and Sterility in the Buck. Pygmy Goat Wor l d M a g a i n . http://kinne.net/fertbuck.htm

5. Wildeus, S. (2015). Reproductive management of the meat goat. Agricultural ResearchService, United States Department of Agriculture; goat

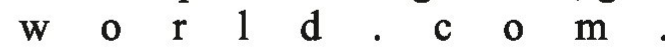
http://www.goatworld.com/articles/pre gnancy/reproductivemanagement.shtm $\underline{1}$

6. Ali., K. M., Ahmad N., Akhtar., N., Ali, S., Ahmad, M. and Yunus, M. (2011). Ultrasound Imaging of Testes and Epididymides of Normal and Infertile 
Breeding Bulls. Pakistan Veterinary Journal, 31(4): 345-350.

7. Pasha, R. H., Qureshi, A. S., Rehman, Z. and Khamas, W.A. (2013). Seasonal Anatomical changes in the testis of the one-humped camel: a review. European Journal of Anatomy, 17 (3):132-141.

8. Andrade,A. K. G., Soares, A. T; Freitas, F. F; Silva, S. V; Peña-Alfaro, C. E., Batista A.M., Guerra M.M.P. (2014). Testicular and epididymal ultrasonography in Santa Inês lambs raised in Brazil. Animal Reproduction, $11(2): 110-118$.

9. Stewart, J. L. and Shipley, C. F. (2014). Breeding Soundness Examination in goats. The Merck Veterinary Manual. http://www.merckvetmanual.com/mv $\mathrm{m} / \mathrm{management}$ and nutrition/breedin g_soundness

10. U $1 \mathrm{ke} \mathrm{r,} \mathrm{H} \mathrm{.,} \mathrm{K} \mathrm{a} \mathrm{n} \mathrm{t} \mathrm{e} \mathrm{r} \mathrm{b,} \mathrm{M} \mathrm{.,}$ Gökdalc, O., Aygüna, T., Karakus, F., Sakaryad, M. E., David, M. A. and Jerry, J. R. (2005). Testicular development, ultrasonographic and Histological appearance of the testis in ram lambs immunized against recombinant LHRH fusion proteins. Animal Reproduction Science, 86: 205 $-219$.

11. Anderson, M. and Alanko, M. (2009). Ultrasonography revealing the accumulation of rete testis fluid in bull testicles. Andrologia, 23 (1): 75-78.

12. Carazo, L. R., Guimarães, J. D., Machado, T. P., Machado, T. P., Oliveira, F. A. andPereira, D. B. (2014). Testicular ultrasonography in young Alpine goats. Arquivo Brasileiro de Medicina Veterinária e Zootecnia, 66 (2): 388-394.
13. Grasselli, F., Galani, R. and Tamanini, C. (1992). Seasonal variation in the reproductive hormones of male goats. ActaEndocrinology, 126:271 - 275.

14. Todini, L., Malfatti, A., Terzano, G. M. and Borghere, A. (2007). Seasonality of plasma Testosterone in Male of four Mediteranean goat breeds and in three different climatic conditions. Therioginology, 67 (3): 627-631.

15. Amrane, A. A., Hammoudi, S. M., Belhamiti, B. T., Selles, S. M.A., Benia, A. R. and Kaidi, R. (2013). Seasonal variation of plasma testosterone levels in Algerian male Arabia goats. African Journal of Biotechnology, 12 (48): 6785-6790.

16. Daramola, J. O., Adeloye, A. A., Fayeye, T. R., Fatoba, T. A. and Soladoye, A.O. (2006). Influence of Photoperiods with or Without Melatonin on Spermiograms in WestAfrican Dwarf Bucks. World Journal of Zoology, 1 (2): 86-90.

17. Leite-Browning, M. (2009). Biology of Reproduction of Goats. Alabama Cooperative Extension System, Alabama $A$ \& $M$ and Auburn Universities. Www.aces.edu/urban

18. McKeown, R. M., O'Callaghan, D., Roche, J. F., Boland, M. P. (1997). Effect of immunization of rams against bovine inhibin alpha 1-26 on semen characteristics, scrotal size, FSH, LH and testosterone concentrations. Journal of Reproduction and Fertility, 109: 237-245.

18. Ochiogu, I. S., Ogwu, D., Uchendu, C.N. , Okoye, C.N. , Ihedioha, J.I. and Mbegbu, E.C. (2015). Serum luteinising hormone, testosterone and 
total cholesterol levels, libido and testicular histomorphology of male West African Dwarf goats orally or subcutaneously treated with monosodium 1-glutamate. Veterinarni Medicina, 60 (5): 253-260.

19. Hafez, B. and Hafez, E. (2000). Reproduction in farm animals, $7^{\text {th }} \mathrm{Ed}$. Lippincott Williams and Wilkins, Philadelphia, U.S.A.

20. Mullen, M. P., Cooke, D. J. and Crow, M. A. (2013). Structural and Functional Roles of FSH and LH as Glycoproteins Regulating Reproduction in Mammalian Species. Chapter 8, INTECH- Science, Technology and Medicine, Open Access Publishers, pp 155-180.

21. Costa, F. L. A., Silva, S.M.M.S. and Nascimento, E.F. (2007). Pathologic evaluation of testis and epididymis of hairy rams in the semi-arid region of Piaui State. Arquivo Brasileiro de Medicina Veterinária e Zootecnia, 59 (5): 1110 - 1116.

22. Abba, Y., Simon, S., Gambo, H. I., Igbokwe, I. O. and Iliyasu, Y. (2014). Pathological Conditions Associated with the Male Reproductive Tract of the Sahel Bucks. Veterinary Medicine International, Article ID 406431, 5 p a g a s http://dx.doi.org/10.1155/2014/406431

23. Raji, L. O., Ajala, O. O. and Ameen, S. A. (2016). Testicular ultrasound as a breeding soundness examination and biometric tool for West African Dwarf goat bucks. Slovakian Journal of Animal Science, 49 (1): 8-16.

24. Raji, L. O. and Ajala. O. O. (2015). Exsitu Morphological and Morphometric studies of the Testis in the West African Dwarf goat buck. Turkish Journal of Agriculture, Food Science and
Technology, 3(11): 886-890.

25. Adebayo, A. O. and Olurode, S. A. (2010). The morphology and morphometry of the epididymis In the greater cane rat (Thryonomys swinderianus temmincks). Folia Morphology, 69 (4): 246-252.

26. Raji, L. O., Fayemi, O. E., Ameen, S. A. and Jagun, A. T. (2012). The effects of aqueous extract of Allium sativum (garlic) on some aspects of reproduction in the female albino rat wister strain). Global Veterinaria, 8: 414-20.

27. Chapwanya, A., Callanan, J., Larkin, H., Keenan, L. and Vaughan, L. (2008). Breeding soundness evaluation of bulls by semen analysis, testicular fine needle aspiration cytology and transscrotal ultrasonography. Irish Veterinary Journal, 61 (5): 315-318.

28. Ahmad, N., Samad, H. A., Rehman, N. U., Ahmad, M. K. and Ahmad, M. (1999). An Ultrasonographic and histopathological study of the testes and epididymis following an Experimentally induced unilateral ischaemia in male goats and rams. Pakistan Veterinary Journal, 19(4): 204-209.

29. Gouletsou, P. G., Galatos, A. D. and Fthenakis, G. C. (2005). Clinical, Ultrasonographic and pathological features following unilateral vasectomy in rams. Animal Reproductive Science, 103 (1-2): 52 68.

30. Ahmad, N. and Noakes, D. E. (1995). A clinical ultrasonographic study of the testes and related Structures of goats and rams after unilateral vasectomy. The Veterinary Record, 137 (5): 112-117. 
31. Babu, S. R., Sadhnani, S. M., Swarna, M., Padmavathi, P. and Reddy P. P. (2004). Evaluation of FSH, LH and testosterone levels in different subgroups of infertile males. Indian Journal of Clinical Biochemistry, 19 (1): 45-49.

32. Fattahi, E., Parivar, K., Jorsaraei, S. G. A. and Moghadamnia, A. A. (2009). The effects of diazinon on testosterone, FSH and LH levels and testicular tissue in mice. Iran. Journal of Reproductive Medicine, 7(2): 59-64.

33. Chakraborty, P. K., Stuart, L. D., \& Brown, J. L. (1989). Puberty in the male Nubian goat: serum concentrations of LH, FSH and testosterone from birth through puberty and semen characteristics at sexual maturity. Animal Reproduction Science, 20(2), 91-101.
34. Abd- El- Maksoud, A. (2005). Morphological, glycol-histochemical and Immunehistochemical studies on the embryonic and adult bovine testis. Ph.D. thesis, Ludwig MaximiliansUniverstat.

35. Nawar, M., Shalaby and Omayma, K. Afifi. (2008). Effect of Experimentally Induced Ischemic-Reperfusion on the Testis and the Possible Protective Role of L-Carnitine in the Adult Albino Rat; Histological, Histochemical and Immunohistochemical Study. Egyptian Journal of Histology, 31 (2): 233 244.

36. Jahan, S., Saeed, N., Ijlal, F., Khan, M. A., Ahmad, M., Zafar, M. and Abasi, A. M.(2009). Histopathological study to evaluate anti-fertility effect of Abrus precatorius $L$. in adult Male mice. Journal of Medicinal Plant Research, 3 (12): 1021 - 1028. 

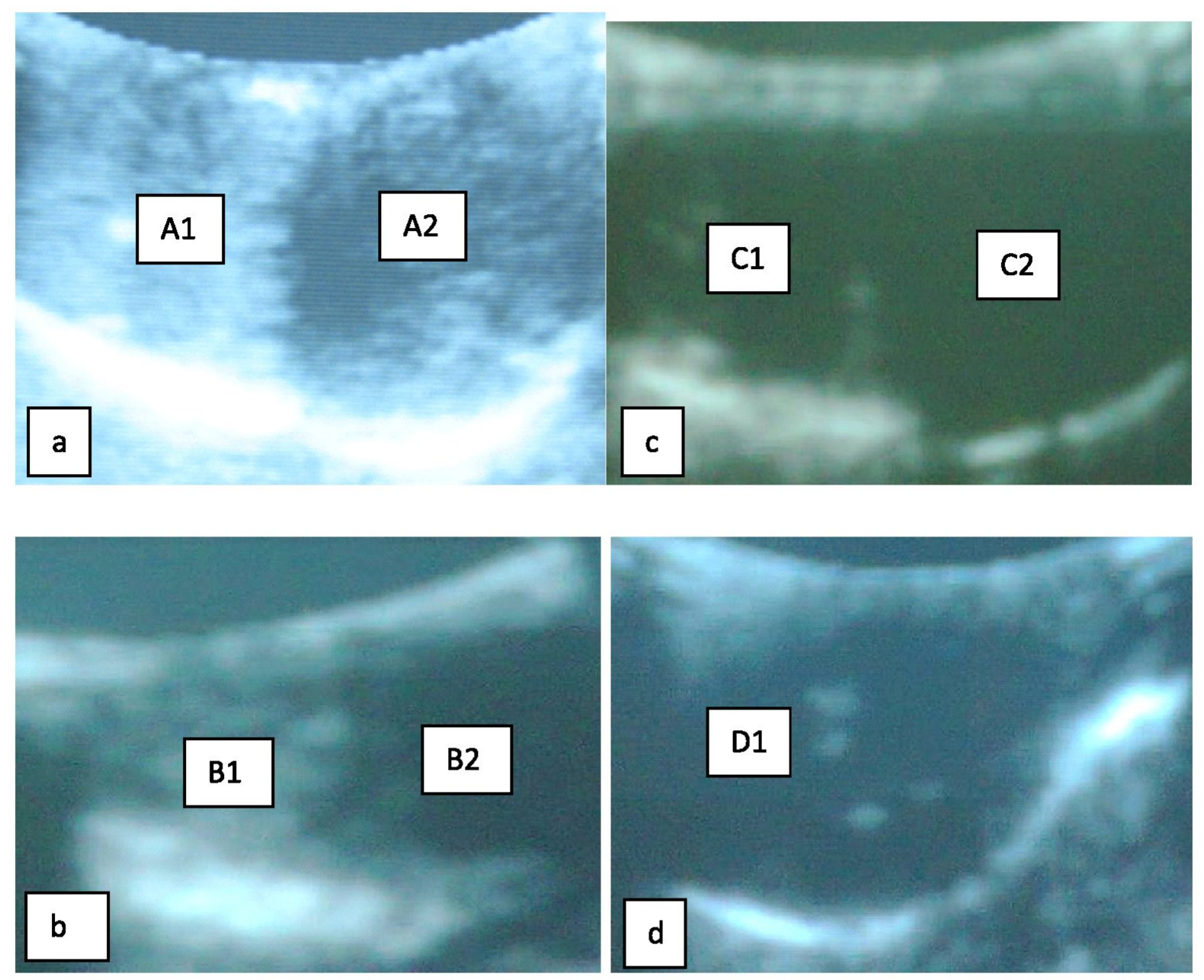

Figure 1: Sonogram for group B bucks - right testes ligated (a) A1 - homogenously grayish but slightly hypoechoic areas of the left testis on TP; and A2 - hypoechoic areas of right testis 24 hours post ligation on TP. (b) B1 - hypoechoic regions of the entire posterior portion of the left testis on TP; and B2 - hypoechoic areas of about two-third of the anterior portion of the left testes. (c) C1 relatively less hypoechoic areas of the left testis; and C2 - entirely hypoechoic areas of the right testis on TP. (d) D1 - entirely hypoechoic regions and areas of fibrosis of right testis on LP. 


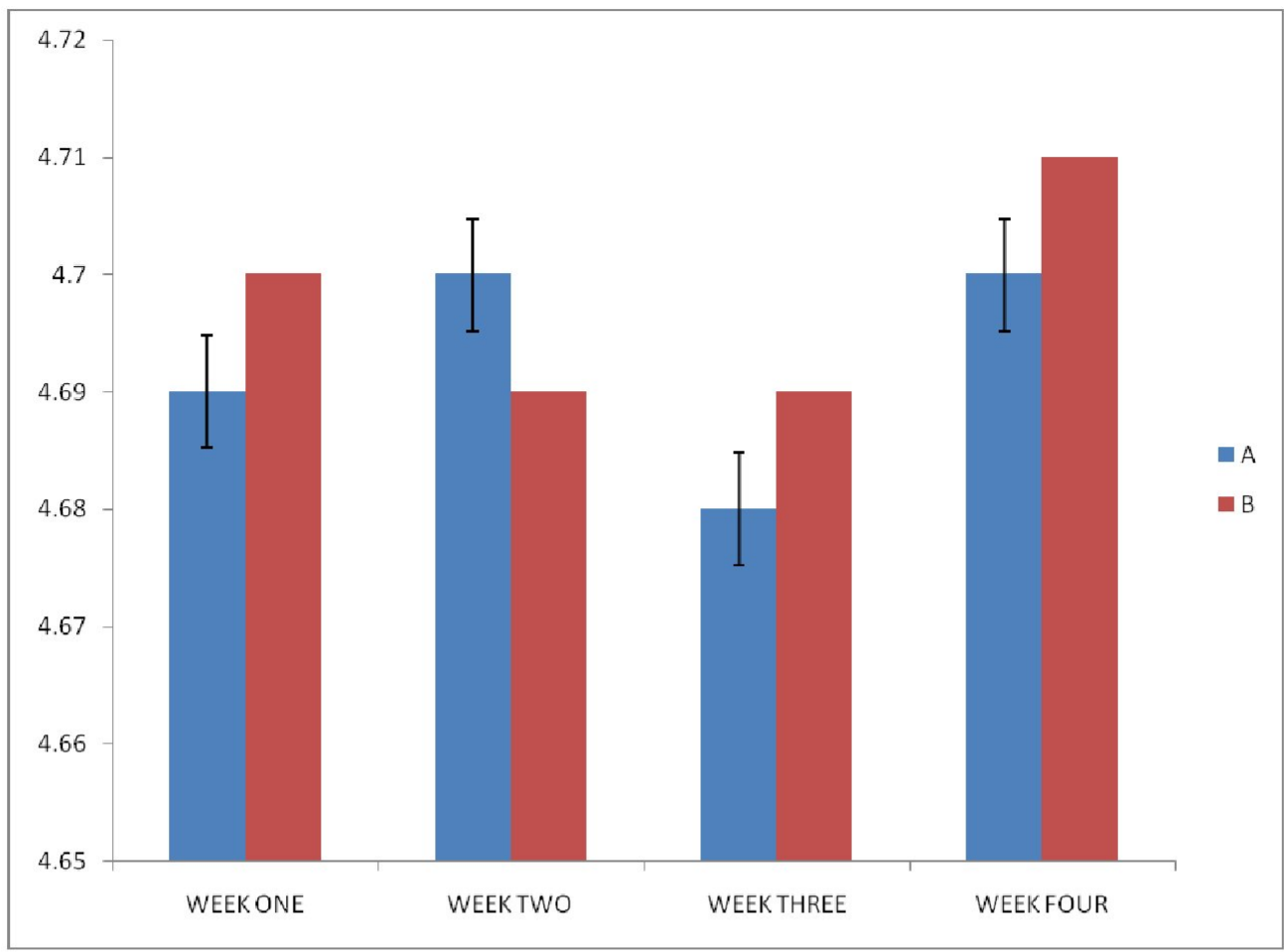

Figure 2: Shows testosterone pattern of the control and right testes ligated West African Dwarf bucks. .

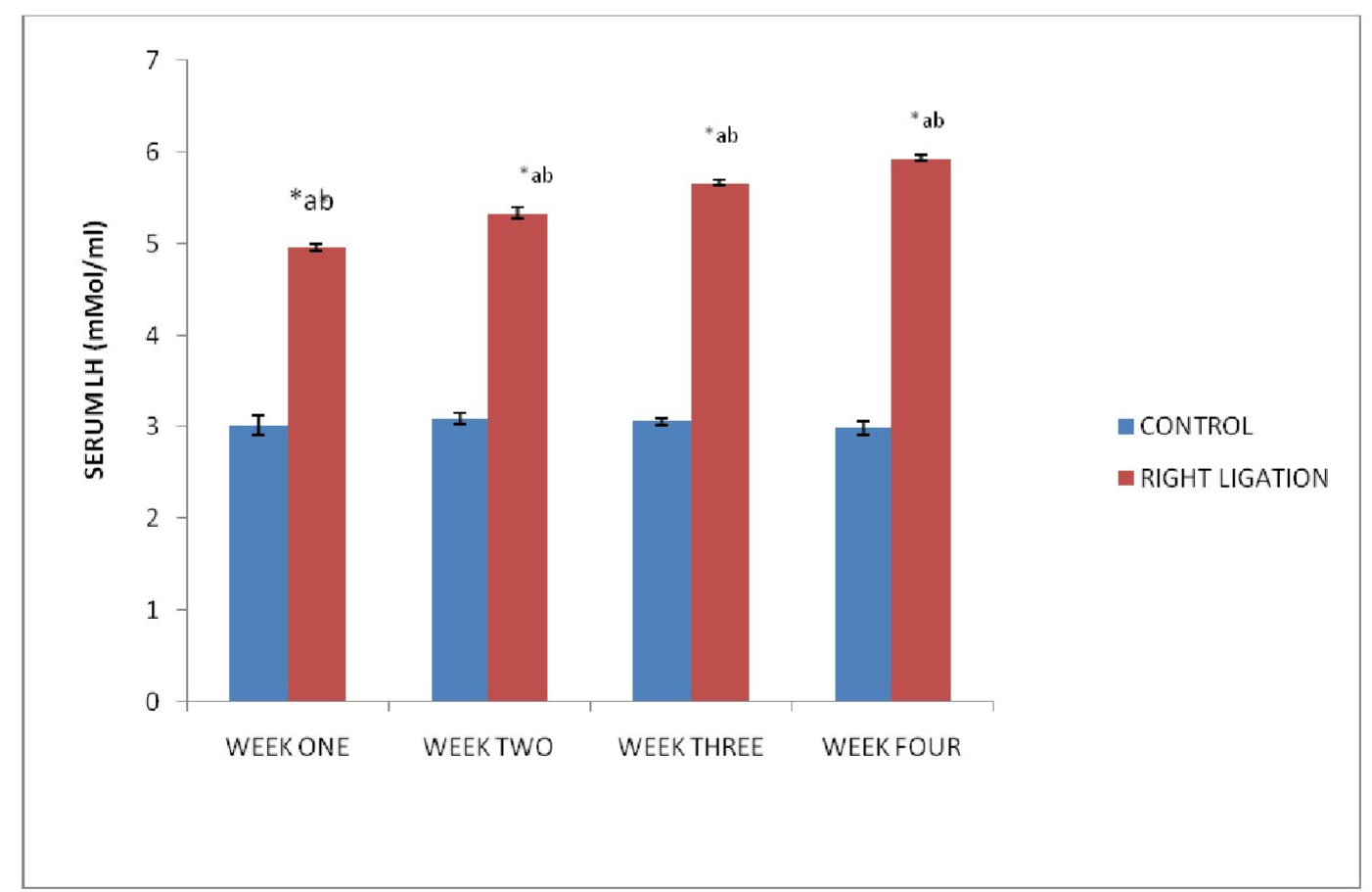

Figure 3: Shows Luteinizing hormone ( $\mathrm{LH})$ pattern of the control and $\backslash$ right testes ligated West African Dwarf bucks. 


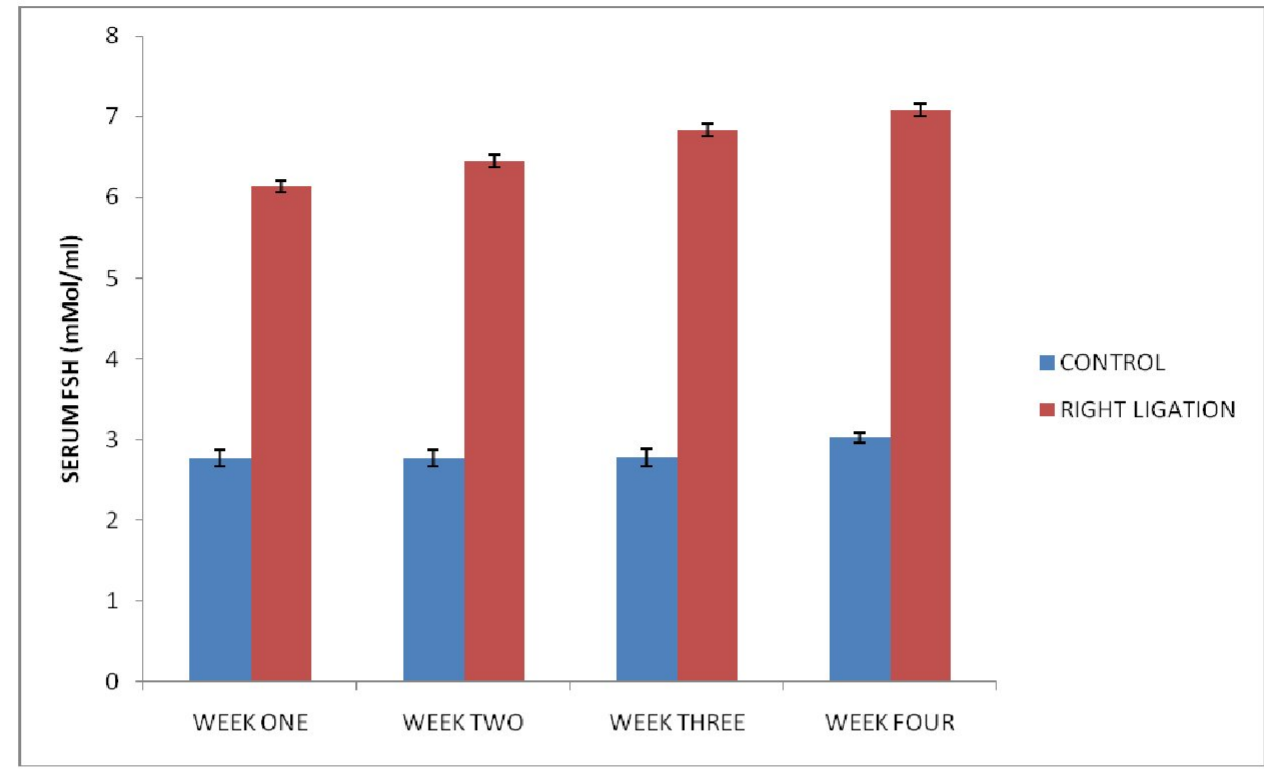

Figure 4: Shows Follicle Stimulating Hormone (FSH) pattern of the control and right testes ligated West African Dwarf bucks.
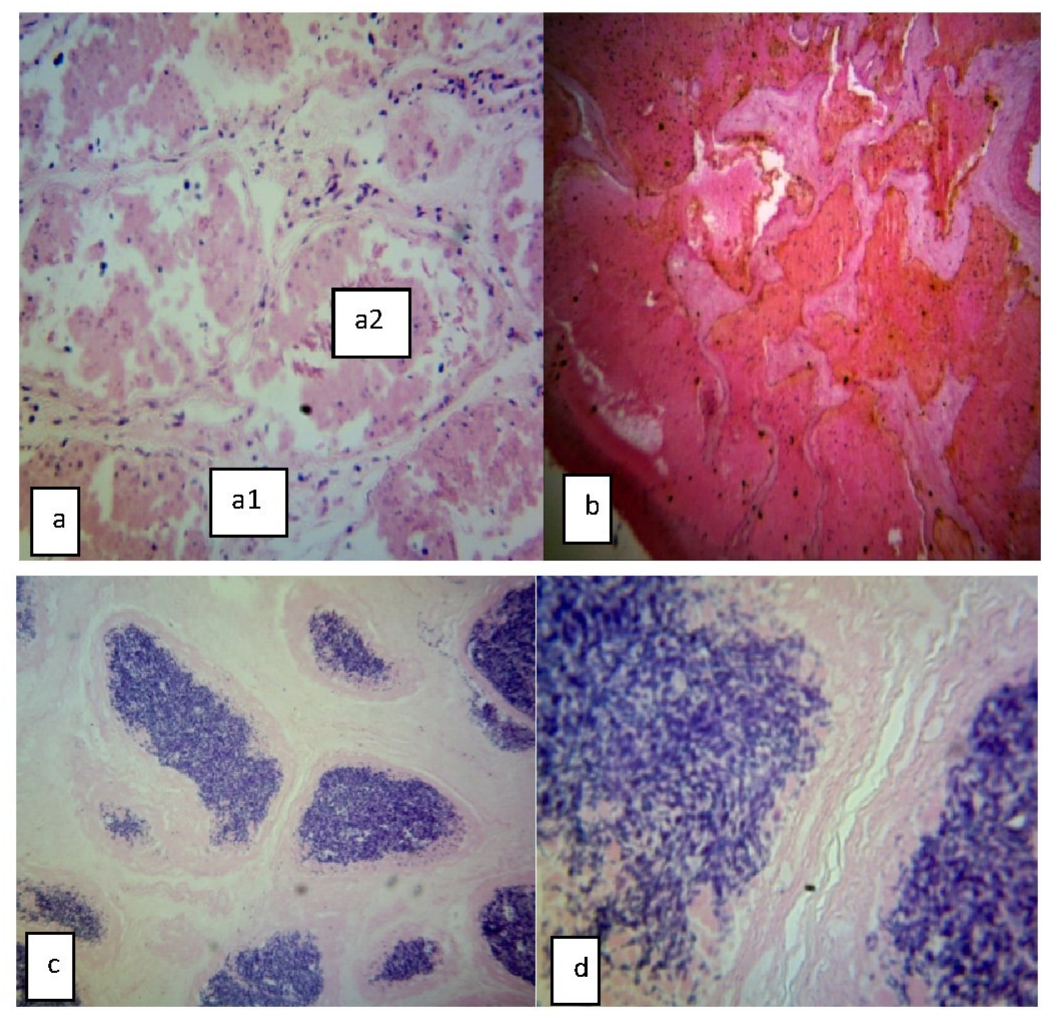

Figure 5: Histopathology of groub B bucks - right testes ligated (a) a1 - intact leydig cells of the right testis; and a2 - complete loss of architecture of the seminiferous tubules (b) complete loss of architecture of the head of epididymis of the right testis. (c) complete loss of architecture of the body of epididymis of the right testis. (d) loss of architecture of the tail of epididymis of the ligated right testis. All the slides were produced with $\mathrm{H} \& \mathrm{E}$ stain and captured with magnification $\times 100$. 
Table 1: Weight and volume of the right and left testes of the control and right testes ligated West African Dwarfbucks - data were expressed in Mean \pm SD

\begin{tabular}{llllll}
\hline Groups & N & WRT (kg) & VRT $\left(\mathbf{c m}^{\mathbf{3}}\right)$ & WLT (kg) & VLT $\left(\mathbf{c m}^{\mathbf{3}}\right)$ \\
\hline A & 6 & $28.3 \pm 1.0^{* \mathrm{a}}$ & $27.9 \pm 0.7^{* \mathrm{ab}}$ & $27.7 \pm 0.6$ & $28.1 \pm 0.9$ \\
& & $\mathrm{~b}$ & & & \\
B & 6 & $14.5 \pm 0.4^{* \mathrm{a}}$ & $14.8 \pm 0.7^{* \mathrm{ab}}$ & $28.4 \pm 1.1$ & $28.7 \pm 1.0$ \\
& & $\mathrm{~b}$ & & & \\
\hline
\end{tabular}

$\mathrm{N}$-number of bucks, WRT - weight of right testis, VRT-volume of right testis, WLT weight of left testis, VLT - volume of left testis. *ab i.e significant when first row is compared with the second row.

Table 2: Total length of the right and left epididymis of the control and right testes ligated West African Dwarf bucks - data were expressed in Mean \pm SD.

\begin{tabular}{llll}
\hline Groups & $\mathbf{N}$ & TLRE (cm) & TLLE (cm) \\
\hline A & 6 & $8.91 \pm 0.27^{* a b}$ & $8.87 \pm 0.2$ \\
B & 6 & $5.02 \pm 0.18^{\text {*ab }}$ & $8.93 \pm 0.3$ \\
\hline
\end{tabular}

$\mathrm{N}$ - number of bucks, TLRE - total length of right epididymis, TLLE - total length of left epididymis. *ab i.e significant when first row is compared with the second row. 